\title{
Private Wells 101: Bacterial Contamination and Shock Chlorination'
}

\author{
Yilin Zhuang and Mary Lusk²
}

\section{Introduction}

The Florida Department of Environmental Protection defines a private well as a water system that "provides piped water to one or two residences, one of which may be a rental residence" (Rule: 62-532.200). An estimated 2.5 million Floridians, or $12 \%$, rely on private wells for home drinking water consumption (Florida Department of Health 2020). While public water systems are monitored under the federal Safe Drinking Water Act, private wells are not regulated (US EPA 2020). Private well users are responsible for the management and protection of their wells.

This EDIS publication is for Florida homeowners who are interested in learning more about their well water system and understanding how to properly shock the well.

\section{Bacterial Contamination in Private Wells}

When heavy rain brings flooding to an area, people do not often think about the damage caused to their private drinking wells. There are two telltale signs that your well has flooded: your wellhead was surrounded by floodwaters, or it was submerged in floodwaters. Sometimes you may also notice the change of color or odor in your well after a storm event. This flooding places your private well in danger of contamination from pollutants found in floodwaters and especially at risk of bacterial contamination.
Having your well water tested following a flooding event is the only surefire way to know if your well has been contaminated or not. The Environmental Laboratory Certification Program was established in 1979 to "ensure laboratory quality and capacity to perform testing of drinking water regulated in the Florida Safe Drinking Water Act" (Florida Department of Health 2020). A list of laboratories accredited by the National Environmental Laboratory Accreditation Program in Florida can be found on the Florida Department of Environmental Protection's website: https://floridadep.gov/dear/florida-dep-laboratory/ content/nelap-certified-laboratory-search.

Before receiving your test results, be sure to use alternative safe water sources (such as bottled water) for drinking, making beverages, cooking, brushing your teeth, washing dishes, and washing areas of the skin that have been cut or injured. You can also bring your well water to a rolling boil for at least one minute to kill bacteria.

If test results reveal bacterial contamination, your well and water system must be disinfected. Nonscented chlorine bleach is often used to disinfect a bacterial-contaminated well (Branz et al. 2017). In addition to disinfecting your well, you must also flush out all household plumbing, including the water heater. If you have water treatment systems or devices, remove all membranes, cartridges, and filters, and replace them after the disinfection process is completed.

1. This document is SL487, one of a series of the Department of Soil and Water Sciences, UF/IFAS Extension. Original publication date February 2021. Visit the EDIS website at https://edis.ifas.ufl.edu for the currently supported version of this publication.

2. Yilin Zhuang, Extension agent I, and Mary Lusk, assistant professor, Department of Soil and Water Sciences, UF/IFAS Gulf Coast Research and Education Center, Wimauma, FL 33598.

The Institute of Food and Agricultural Sciences (IFAS) is an Equal Opportunity Institution authorized to provide research, educational information and other services

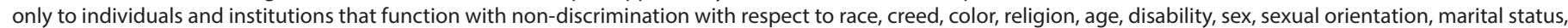

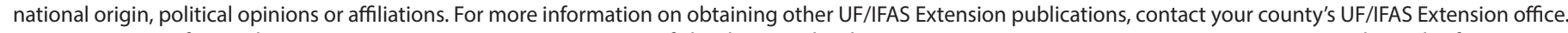
U.S. Department of Agriculture, UF/IFAS Extension Service, University of Florida, IFAS, Florida A \& M University Cooperative Extension Program, and Boards of County Commissioners Cooperating. Nick T. Place, dean for UF/IFAS Extension. 


\section{Effectiveness of Chlorine Bleach}

On average, common household nonscented bleach contains 5\%-6\% sodium hypochlorite, more commonly known as chlorine. Nonscented splashless bleach is slightly thicker than regular household bleach, making it less likely to splash; however, the sodium hypochlorite concentration is only $1 \%-5 \%$. At these concentrations, nonscented splashless bleach is not strong enough to sanitize and disinfect your well. As the label warns, you will be left with suds in your water. If you have already used splashless nonscented bleach, you will need to flush your well system longer to remove all the suds.

Before disinfecting your well, be sure to check the "sell-by date" because bleach loses strength in its container over time. If you cannot purchase a new container of bleach, try to use bleach that is less than three months old. Nonscented bleach is preferred to avoid adding unneeded chemicals to the well.

To make the disinfection procedure more effective, make sure the $\mathrm{pH}$ of the water in the well is between 6.5 and 7 (Pieper et al. 2020). If the $\mathrm{pH}$ of your well is not in this range, consult a well treatment professional to adjust the $\mathrm{pH}$ and maintain it in the correct range during the disinfection process.

\section{Drinking Well Shock Chlorination Disinfection Procedure}

The Florida Department of Health recommends taking the following steps to disinfect a bacterial-contaminated private drinking water well.

1. Pump out the well to remove any potential contaminants. Generally, pump out at least three well volumes of water from a faucet near the wellhead. If you do not know your well size, pump the well for at least 1 hour before beginning the shock chlorination disinfection process.

2. Flush out all household plumbing, including the water heater. Make sure the water is clear and free of sediment. If you have not drained your water heater, you may have to drain it twice to completely drain all the sediments in the bottom of your water heater.

3. Turn off electric power to the pump and remove the well cap. Keep in mind, every time you open your well cap, you increase the chances of bacterial contamination.
4. Prepare a solution of sodium hypochlorite and water and pour the solution into the top of the well. Diluting sodium hypochlorite will reduce the chance of corrosion of the well system. Please note: do not mix chlorine solutions with other cleaning products, including ammonia, because toxic gases will be created. Sodium hypochlorite is usually found in nonscented household bleach. The amount of nonscented bleach depends on the depth of water in the well and the diameter of the well casing. The solution should be diluted with a 1:10 ratio of nonscented bleach to water. For example, when mixing a solution for a 2" diameter and 100-foot-deep well, mix 1 cup of bleach with 10 cups of water before pouring it into your well. Table 1 provides standard ratios of nonscented bleach to water for typical well sizes. Typical Florida drilled wells are 2 " in diameter and approximately 100 feet in depth for residential wells and 4" in diameter and approximately 150 feet in depth for agricultural wells. Be sure to review "Effectiveness of Chlorine Bleach" (above) when mixing a nonscented bleach solution.

5. Recirculate the water in the well by connecting a hose to a faucet and spraying the water back into the well for at least 10 minutes.

6. Open every faucet in the system and let the water run until the smell of chlorine can be detected. Then, close all the faucets and seal the top of the well.

7. Allow the chlorinated water to stand in the system for at least 12 hours but no longer than 24 hours.

8. The next day, operate the pump by turning on all faucets, beginning with outside and flushing out the water until there is no chlorine odor.

9. Test well water again in 5 to 10 days to make sure there is no bacterial contamination. If bacteria are still present, you may need to repeat the process to remove longestablished bacterial colonies. If the problem persists, you need to contact a water treatment professional familiar with bacterial contamination in wells.

The shock chlorination process outlined above is only effective for treating bacterial contamination. When you have elevated nitrate or lead concentration in your drinking well, shock chlorination will not reduce concentrations of these contaminants. Meanwhile, shock chlorination is not a continuous disinfection method. It is only recommended after construction of a new well, after working on an existing well or installing a new submersible pump, or after receiving a positive water test report for coliform bacteria. 
If your test result shows bacteria positive again, you may need to think about a continuous disinfection method, such as chlorination injection tank or ultraviolet (UV) disinfection, to ensure your water is safe to drink.

Even after shock chlorination, bacterial contamination can reoccur in your well due to problems caused by source contamination. Common sources of contamination include a nearby malfunctioning septic system, an improper well location, the absence of a well cap, an improperly placed or loose well cap, inadequate grouting or other construction problems during well construction, or a cracked well casing.

\section{References}

Branz, A., M. Levine, L. Lehmann, A. Bastable, S. I. Ali, K. Kadir, T. Yates, D. Bloom, and D. Lantagne. 2017. "Chlorination of Drinking Water in Emergencies: A Review of Knowledge to Develop Recommendations for Implementation and Research Needed." Waterlines 36 (1): 4-39. https:// doi.org/10.3362/1756-3488.2017.002

Florida Department of Health. 2020. "Private Well Testing." http://www.floridahealth.gov/environmental-health/ private-well-testing/index.html

Pieper, K. J., W. J. Rhoads, L. Saucier, A. Katner, J. R. Barrett, and M. Edwards. 2020. "Improving State-Level Emergency Well Disinfection Strategies in the United States." Science of the Total Environment 720:137451.

US Environmental Protection Agency. 2020. "Private Drinking Water Wells.” https://www.epa.gov/privatewells 
Table 1.6\% Sodium Hypochlorite Rates Relative to Well Depth and Diameter.*

\begin{tabular}{|c|c|c|c|}
\hline \multirow{2}{*}{ Well Depth in Feet } & \multicolumn{3}{|c|}{ Well Diameter in Inches } \\
\cline { 2 - 4 } & $\mathbf{2 \prime}$ & $\mathbf{4}^{\prime \prime}$ & 2 cups \\
\hline $50^{\prime}$ & 1 cup & 2 cups & 4 cups \\
\hline $80^{\prime}$ & 1 cup & 2 cups & 4 cups \\
\hline $100^{\prime}$ & 1 cup & 3 cups & 8 cups \\
\hline $150^{\prime}$ & 2 cups & 4 cups & 10 cups \\
\hline $200^{\prime}$ & 3 cups & 6 cups & 12 cups \\
\hline * Table 1 is adapted from the Florida Department of Health publication “What Should I Do If My Well Is Flooded?" (Florida Department of \\
Health 2020). Common household nonscented bleach contains 5\%-6\% sodium hypochlorite.
\end{tabular}

